$[ノ-ト]$

\title{
走査プロープ顕微鏡による(ポリプロピレン/エラストマー粒子)系 ブレンド界面の評価
}

\author{
中原 重樹*1 ·本岡 正則 $* 1 \cdot$ 田中 敬二*2
}

高原 谆*3 $\cdot$ 梶山 千里*4

（受付 2005 年 1 月 21 日·審査終了 2005 年 6 月 3 日）

\section{1 緒言}

高分子材料は異種高分子を混合することによって新た な特性を付与できる.このため, 実用材料の多くは単独 による使用ではなくブレンド系となっている. ポリプロ ピレン(PP)の低温ゼイ性や耐衝撃性はゴム弾性を有す る(エチレン/ブテン)系エラストマー(EBR)をブレンド することで改良されている.ブレンド采の物性発現には 粒系, 分散などのモルホロジーや相界面の構造が大きく かかわっていると考えられる.このため相界面の構造を 評価することは，材料設計に指針を与える観点からも極 めて重要である.

本報では，走査フォース顕徽鏡 $(\mathrm{SFM})$ を用いて， PP とEBR を溶融混練して調製した試料におけるPPEBR 相分離界面の厚さを評価・検討した結果について 報告する.

\section{2 実験}

\section{1 試料}

本報に用いた PP および EBR の諸物性を Table 1 に 示す.これらの原料を $\mathrm{PP} / \mathrm{EBR}=80 / 20(\mathrm{wt} \%)$ の割合で Thermo Electron Co. 製簡易型 2 軸混練機にて溶融混練 し,ブレンド試料を得た.

\section{2 試料前処理と測定方法}

\subsection{1 試料前処理}

溶融混練で作製したポリマーブレンドは，その表面に 応力や温度の不均一性に伴ない内部と異なる相分離状態 が形成される.このため, ポリマーブレンド内部の相分

*1 (株)三井化学分析センター(亚299-0265 袖ヶ浦市長浦 580-32)

*2 九州大学大学院工学研究院 (业812-8581 福岡市東区箱崎 6-10-1)

*3 九州大学先導物質化学研究所 (\$812-8581 福岡市東区箱 崎 6-10-1)

*4 九州大学(乯812-8581 福岡市東区箱崎 6-10-1)
Table 1. Characterization of PP and EBR

\begin{tabular}{ccccccc}
\hline \hline & $\begin{array}{c}\rho \\
\left(\mathrm{Kg} / \mathrm{m}^{3}\right)\end{array}$ & $\begin{array}{c}T_{\mathrm{c}} \\
\left({ }^{\circ} \mathrm{C}\right)\end{array}$ & $\begin{array}{c}T_{\mathrm{m}} \\
\left({ }^{\circ} \mathrm{C}\right)\end{array}$ & $\begin{array}{c}T_{\mathrm{g}} \\
(\mathrm{K})\end{array}$ & $\begin{array}{c}x_{\mathrm{c}}^{\mathrm{a})} \\
(\%)\end{array}$ & $\begin{array}{c}\left.\mathrm{C}_{2}^{\mathrm{b}} \mathrm{\%}\right) \\
(\mathrm{mol} \%)\end{array}$ \\
\hline h-PP & 910 & 131 & 168 & - & 83 & - \\
\hline EBR & & & & & & \\
1 & - & - & - & 203 & - & 65 \\
2 & - & - & - & 223 & - & 91 \\
\hline a) DSC, & b) Ethylene content. & &
\end{tabular}

a) DSC, b) Ethylene content.

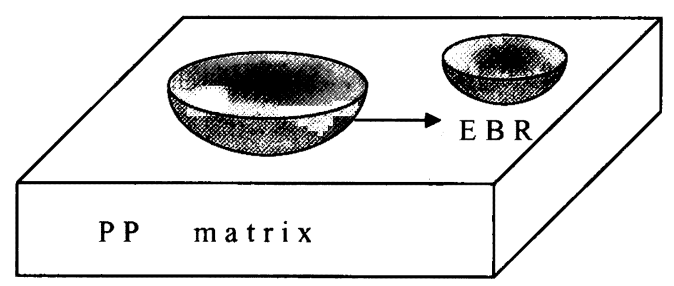

離状態を走査フォース顕微鏡 $\left(\mathrm{SFM}^{\mathrm{l})}\right)$ で評価するために は，平滑な観察表面を作製する必要がある. PP, EBR ともにガラス転移温度は室温以下であるため, 観察表面 作製(面だし)にはクライオミクロトームを用いた切削を 行った. 切削温度, 切削速度, ダイヤモンドナイフの種 類, 切片厚みなどの諸条件を最適化することにより平均 表面粗さが $\mathrm{Ra}$ 值で $17 \mathrm{~nm}$ の観察試料を調製した. TEM 観察用試料はクライオミクロトームでトリミング 後, $\mathrm{Ru}_{3} \mathrm{O}_{4}$ 蒸気で 12 時間染色し, 再度クライオミクロ トームにて厚み $100 〜 150 \mathrm{~nm}$ の薄片に切り出した.

\subsection{2 測定方法}

SFM 装置はエスアイアイナノテクノロシー(株)製 SPA300を使用した。走査範囲を $20 \times 20 \mu \mathrm{m}^{2}$ とし，バ ネ定数 $0.03 \mathrm{~N} / \mathrm{m}$ のカンチレバーを用いた粘弾性モード で測定した. ステーシ振動条件は $4 \mathrm{kHz}, 5 \mathrm{~nm}$ であり, 環境は室温大気下である。

TEM は (株) 日立製作所製 H-7000を使用し，加速電

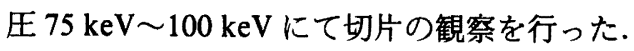




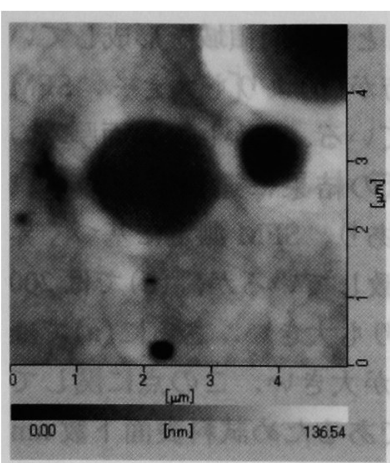

(a) height

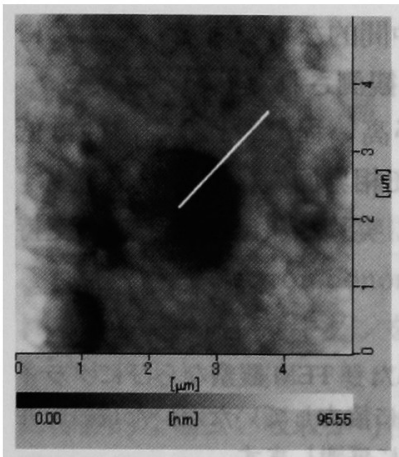

(c) height

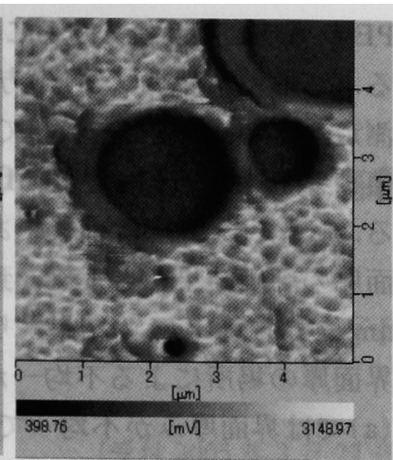

(b) a mplitude

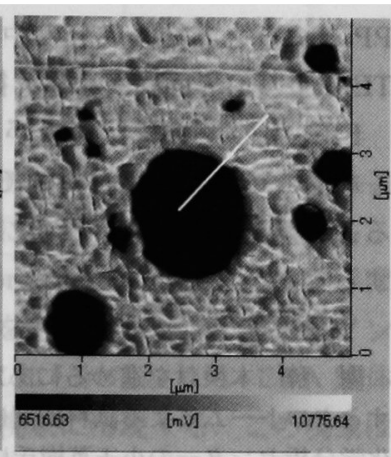

(d) amplitude
Figure 1. SFM images: (a), (b) $P P / E B R-1=80 / 20$, (c), (d) PP/EBR-2.

\section{3 結果と考察}

Figure 1 は $(\mathrm{PP} / \mathrm{EBR}=80 / 20)$ ブレンド試料断面の SFM 観察像である.（a)，(b)はそれぞれ(PP/EBR-1= $80 / 20$ )の形状像 (height image) と振幅像 (amplitude image)であり，(c)，(d)はそれそれ（PP/EBR-2=80/20)の 形状像と振幅像である.ここで EBR-1 と EBR-2 は土チ レン含量が異なる．EBR-1のエチレン含量は $65 \mathrm{~mol} \%$ であり，EBR-2のエチレン含量は $91 \mathrm{~mol} \%$ のある.PP 中に粒子径数ミクロンのEBR が分散している. 形状像 において EBR はPPよりも低い高さの領域として観察 されている.これは観察試料を低温で作製した後, 室温 に戻す際に生じた応力緩和によるものと考えている．す なわち切削前の EBR 粒子はPP で等方的に曲まれてい るため混練機でブレンドする際の配向が残った状態にあ るが，切削によって自由表面が形成されると配向による 応力を緩和するために変形し，その結果 EBR が凹んた ものと考える. 振幅像は試料ステージを正弦的に振動さ せた際のカンチレバーの応答振幅に対応し ${ }^{1)}$, 試料表面 の弾性率を反映している。このため，PP 相は明るく， また，EBR 相は暗い領域として観察されている．振幅 像において EBR 粒子の輪郭を比較すると，（b)では PP 相との境界に両相の中間的なコントラストが見られるの

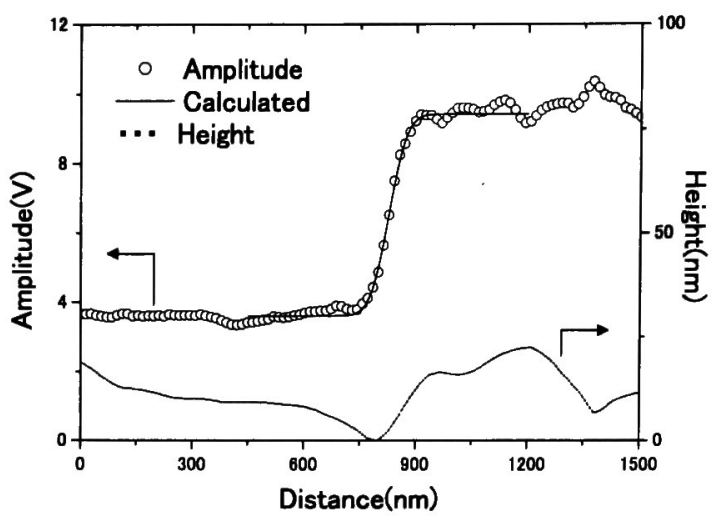

Figure 2. Line profiles of height and amplitude along each line drawn in the parts (c) and (d) of Figure 1.

に対し，(d)では見られない。これは用いた EBRのエ チレン含量による相溶性の違いを反映していると予想さ れたため, 以下により詳細な解析を行った。

Figure 2 は Figure 1 の (c)および(d)の白線上におけ る形状と振幅のラインプロファイルである. 振幅像のプ ロファイルはEBR 粒子界面において著しく変化し ており, 試料表面の粘弾的な性質の変化を示している (PP/EBR). 界面近傍におらける振幅プロファイルをガウス 分布関数 $\phi(x)$ でフィットすることで, 界面の広がりを 評価した.

$$
\phi(x)=A / \sigma \sqrt{2 \pi} \cdot \exp \left[-\frac{1}{2}\left(\frac{x-m}{\sigma}\right)^{2}\right]
$$

ここで， $m$ は分布の中心， $\sigma$ は標準偏差である. 正規分 布では全データの $68 \%$ が $m$ を中とした $2 \sigma$ の範囲に 入るため $2 \sigma$ を界面の広がりと定義した ${ }^{2)}$ 。一方，この 界面領域における形状像の高低差はプロファイルライン の方向を変えても 7 $10 \mathrm{~nm}$ と比較的小さく，その変化 はなだらかであるため, 振幅像の変化に与える影響は小 さく無視できると仮定した，さらに，針の位置はフィー ドバックがかかっており，表面に対して相対的に同じ位 置に保たれるため測定上は傾斜の影響は無視できると考 えられる. (PP/EBR-1 = 80/20) および $(\mathrm{PP} / \mathrm{EBR}-2=80 /$ 20)の界面厚は，それぞれ $116 \pm 34,80 \pm 6 \mathrm{~nm}$ であっ た.この結果は, 前者の方が EBR 中のエチレン含量が 低くPP との相溶性が高いこととよく対応している.

EBR 中のエチレン含量と界面厚の関係をさらに検討 するために，TEM 観察を行った． Figure 3 は EBR 分散 粒子と PP 界面の TEM 像である. 非晶の EBR 相はル テニウムによって染色されているため暗く観察されてい る3). また Figure 3(b)では，EBR 相中のエチレンブロ ックラメラも明確に観察されている. 一方, PP 相の非 晶部分もルテニウム酸によって染色されているため, 結 晶構造の立体規則性を反映した PP ラメラのクロスハッ チ構造が明瞭に観察されている. 界面付近のPPラメラ 


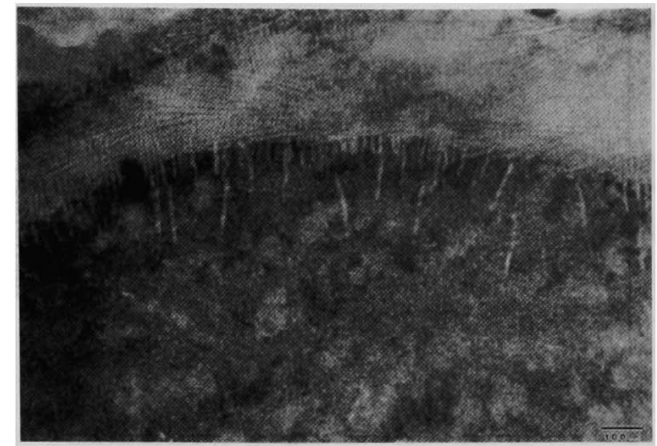

(a) $\mathrm{h}-\mathrm{P} \mathrm{P} / \mathrm{EBR}-1=80 / 20$

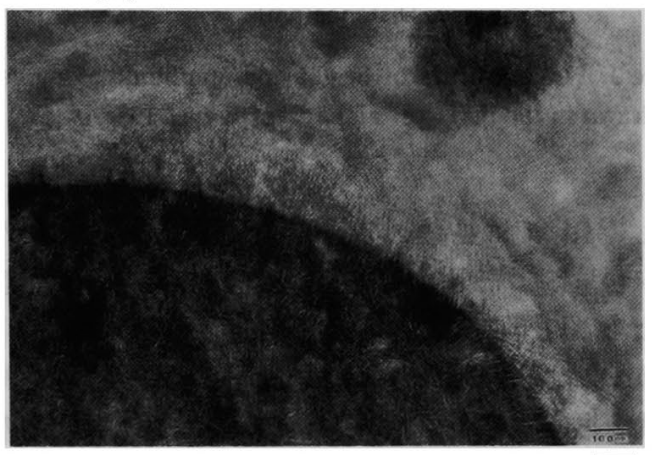

(b) $\mathrm{h}-\mathrm{PP} / \mathrm{EBR}-2=80 / 20$

$100 \mathrm{~nm}$

Figure 3. TEM images for PP/EBR interface.

の厚みは Figure 3(a)の方が大きい。これは Figure 3(a) でのEBRのエチレン含量が Figure 3(b)よりも小さく Melt Index 值が大きいためPP が結晶化する温度に抢け るEBR の運動性が大きくなり，その結果 PP ラメラの 成長を促進したものと考える.

PP ラメラは EBR 分散粒子内部に侵入し， EBR 中の
PE ラメと相互侵入することで界面領域を形成してい る.この侵入深さは (a)の方が(b)よりも大きく, SFM 測定の結果と傾向は一致している.しかし，界面厚みの 値に関してはTEM と SFMの結果に違いが認められ る.（b）では $100 \mathrm{~nm}$ 前後であり, SFM 測定に基つくく界 面厚の評価結果ともよく一致しているが，(a)では 200 $\mathrm{nm}$ 位であり SFMの結果よりも大きい.さらに(a)では 界面厚の場所による不均一が大きい。この点に関して (a)では界面厚みが不均一であるため試料表面下数 nm の物性を観測する SFM 測定において，PP メラ表面 に存在する非結晶成分の影響が大きくSFMの応答が PP ラメラと非結晶成分の中間的なものとなったために TEM よりも界面厚が小さく観測されたものと考える.

EBR 中のエチレン含量が高い程 PP との相溶珄は低 くなる.このため, 試料間で相界面の構造に変化が生ず ることが予想されていたが，実験結果はこの予想を支持 するものとなった.

謝 辞 本検討を進めるにあたり TEM 観察ならびにクライ オミクロトームによる試料切削に協力していただいた(株)三井 化学分析センターの小玉英樹氏に感謝します.

文献

1) T. Kajiyama, K. Tanaka, I. Ohki, S.-R. Ge, J.-S. Yoon, and A. Takahara, Macromolecules, 27, 7932 (1994).

2) D. Kawaguchi, K. Tanaka, A. Takahara, and T. Kajiyama, Macromolecules, 34, 6164 (2001).

3）朝倉健太郎，広畑泰久, “ウルトラミクロトーム技法 Q \& $\mathrm{A}^{\prime}$, アグネ承風社, 東京 (1999).

\section{[Notes]}

Evaluation of Interfacial Structure in Blends of Polypropylene and Elastomer by Scanning Force Microscopy

Shigeki NaKahara, ${ }^{* 1}$ Masanori Motowoka, ${ }^{* 1}$ Keiji Tanaka, ${ }^{* 2}$ Atsushi TaKahara, ${ }^{* 3}$ and Tisato Kajiyama ${ }^{* 4}$

${ }^{* 1}$ Mitsui Chemical Analysis \& Consulting Service Inc. (580-32 Nagaura, Sodegaura 299-0125, Japan)

*2 Department of Applied Chemistry, Kyushu University (6-10-1 Hakozaki, Higashi-ku, Fukuoka 812-8581, Japan)

*3 Institute for Materials Chemistry and Engineering, Kyushu University (6-10-1 Hakozaki, Higashi-ku, Fukuoka 812-8581, Japan)

${ }^{* 4}$ Kyushu University (6-10-1 Hakozaki, Higashi-ku, Fukuoka 812-8581, Japan)

Flat cross-sections of (polypropylene/elastomer) blends were prepared by ultamicrotoming at $150 \mathrm{~K}$. Then, scanning force microscopy (SFM) was applied to each cross-section to evaluate the interfacial thickness between the two phases in the blend. For this purpose, a viscoelastic mode was superior to a conventional topographic mode. The results obtained well reflected the solubility between the two components. Finally, transmission electron microscopy was applied to the sample. The TEM observations supported what was suggested on the basis of SFM results.

KEY WORDS Polymer Blend / Interfacial Structure / Scanning Force Microscopy /

(Received January 21, 2005: Accepted June 3, 2005)

[Kobunshi Ronbunshu, 62(9), 432-434 (2005)] 